\title{
Study on application of iron tailings fine aggregate in concrete

\author{
Ke Tang ${ }^{1, a,{ }^{*}}$, Xuesong Mao ${ }^{1, b}$, Xinlei Tang ${ }^{1}$ \\ 'School of highway, Chang'an University, Xi'an, 710064, China \\ aemail: 13519199173@163.com \\ bemail: bxuesongxian@aliyun.com
}

Key words: Iron tailings, Mix design, Workability, Slump.

\begin{abstract}
Natural sand plays a unique role in the mix proportion of road cement concrete, however, the stock of natural sand in our country is very limited. In order to find the material that can replace the natural sand without affecting the performance of the concrete, the paper compares the physical properties of iron tailings with natural sand and designs the proportion of road cementitious concrete with iron tailings instead of natural sand. The use of iron ore tailings can not only solve the problem of iron tailings storage, natural sand supply and raw material cost, but also turn waste into treasure, improve the environment and contribute to economic construction. On this basis, slump detection analysis, workability analysis and mechanical properties of compressive strength test results show that: the sand rate of about $24.4 \%$, and the particle size of $0.15--0.30 \mathrm{~mm}$ when the corresponding The amount of iron ore tailings corresponding to the best proportion of concrete mix.
\end{abstract}

\section{Introduction}

With the vigorous development of infrastructure construction, there is an increasing demand for the amount of cement concrete used in roads. Cement, gravel, natural sand, water and water reducer are the necessary materials for composing road cement concrete ${ }^{[1]}$. At present, the storage and supply of natural sand in our country is very limited, so we must seek for the material that can both replace natural sand and cement concrete performance. The concrete prepared by substituting natural tailings with iron tailings not only can reduce the tailings a lot and improve the environment, but also can ensure sufficient supply of materials and lay the foundation for infrastructure construction ${ }^{[2]}$. In the past, the research on iron tailing sand mostly focused on the experimental study of iron tailings sand used as fine aggregate or admixture to change the workability, sand rate and strength of concrete $^{[3]}$ found: the amount of tailings to replace natural sand changes the workability and mechanical properties of concrete; Sun Xiaowei used iron tailings as aggregates to prepare grouting material ${ }^{[4]}$. It was found that iron tailing sand changed the sand rate in concrete and made the workability and strength changed. However, there is little research on tailing sand as a cementitious material to influence workability and mechanical properties.

Based on the above situation and the purpose of this paper, the physical properties of iron tailings and natural sand were compared to analyze the substitutability of iron tailings and natural sand. Then, slump analysis, workability analysis and mechanical properties testing of compressive strength of concrete were carried out by comparing the proportion of natural tailings of iron tailings with different particle sizes and different proportions. Multiple trials to meet the above requirements of the mix design.

\section{Experimental design}

\subsection{Experimental test program}

Test design, should be screening materials, mix design, concrete mixing, specimen production, specimen maintenance cycle, compressive strength testing. 


\subsection{Material composition}

\subsubsection{Tailings sand extraction and physical properties}

When iron ore tailings are prepared, the process of extracting fine sand for construction is shown in Fig. 1, in which the composition of the iron tailings particles is shown in Table 1, and the physical property comparison table of iron tailings and natural sand is shown in Table 2.

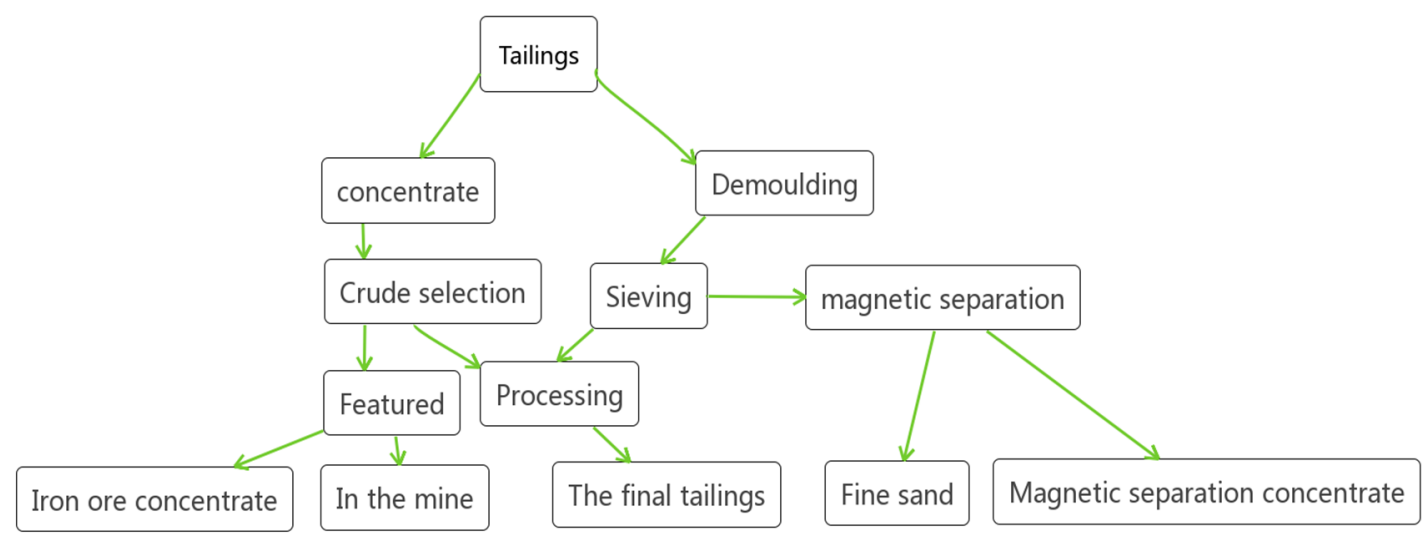

Fig.1 Flow chart of extracting construction sand

Table 1 Tailings particle composition table

\begin{tabular}{ccccccccccccc}
\hline \multirow{2}{*}{$\begin{array}{c}\text { Type of } \\
\text { mine }\end{array}$} & $\begin{array}{c}\mathrm{SiO} \\
2\end{array}$ & $\mathrm{Al}_{2} \mathrm{O}_{3}$ & $\mathrm{Fe}_{2} \mathrm{O}_{3}$ & $\mathrm{TiO}_{2}$ & $\mathrm{MgO}$ & $\mathrm{CaO}$ & $\mathrm{Na}_{2} \mathrm{O}$ & $\mathrm{K}_{2} \mathrm{O}$ & $\mathrm{SO}_{3}$ & $\mathrm{P}_{2} \mathrm{O}_{5}$ & $\mathrm{MnO}$ & Iron burning \\
\hline $\begin{array}{c}\text { Anshan- } \\
\text { style iron } \\
\text { ore }\end{array}$ & 73. & 4.07 & 11.6 & 0.16 & 4.22 & 3.04 & 0.41 & 0.95 & 0.25 & 0.19 & 0.14 & 2.18 \\
\hline
\end{tabular}

Table 2 Iron tailings and natural sand physical properties comparison table

\begin{tabular}{ccccccc}
\hline & $\begin{array}{c}\text { Apparent } \\
\text { density }\end{array}$ & $\begin{array}{c}\text { Bulk } \\
\text { density }\end{array}$ & $\begin{array}{c}\text { Powder } \\
\text { composition }\end{array}$ & $\begin{array}{c}\text { Crush the } \\
\text { value }\end{array}$ & $\begin{array}{c}\text { Fineness } \\
\text { modulus }\end{array}$ & $\begin{array}{c}\text { Iron phase } \\
\text { minerals }\end{array}$ \\
\hline $\begin{array}{c}\text { Natural fine } \\
\text { sand }\end{array}$ & 2650 & 1410 & Soil particles & $10 \%$ & $1.6 \sim 2.2$ & $5 \% \sim 10 \%$ \\
\hline $\begin{array}{c}\text { Iron tailings } \\
\text { sand }\end{array}$ & 2770 & 1540 & $\begin{array}{c}\text { Stone powder } \\
\text { particles }\end{array}$ & $5 \%$ & $0.9 \sim 1.8$ & $1 \%$ \\
\hline
\end{tabular}

Table 2 Comparison of the physical properties of natural fine sand and iron tailings, the important difference between the two is the composition of fine powder and iron phase minerals. Among them, most of the fine powder contained in the iron tailings is stone powder particles, and the stone powder is favorable for the mechanical properties, durability, cohesiveness and workability of the concrete; however, the content of the fine powder contained in the natural fine sand is mainly the soil particles Particles are not conducive to concrete workability, mechanical properties and durability ${ }^{[5]}$. A lot of literature shows that the content of stone powder in iron tailings can change the properties of concrete, so iron tailings can be used as cement-concrete compound materials.

\subsubsection{Other materials}

The experimental materials used, using 32. 5 (R) ordinary portland cement, cement strength coefficient of surplus of 1.13 , cement density: $3100 \mathrm{~kg} / \mathrm{m}^{3}$; stone: the maximum particle size of $20 \mathrm{~mm}$ gravel, the density of $2780 \mathrm{~kg} / \mathrm{m}^{3}, 0.8 \%$, fineness modulus of 2.7 ; water for ordinary tap water, water density: $1000 \mathrm{~kg} / \mathrm{m}^{3}$; superplasticizer for the HSP superplasticizer.

\subsection{With the design}

The proportion of the design, the use of volume method to calculate the thickness of aggregate, cement, water quality as shown in Table 3 below, tailings sand because of its smaller size, so the increase in the amount of cementitious material means that the increase in water Ash ratio is reduced. 
Table 3. Raw material composition of the scale

\begin{tabular}{|c|c|c|c|c|c|c|c|c|c|}
\hline \multirow{2}{*}{$\begin{array}{l}\text { Failings } \\
\text { particle size } \\
\text { range }(\mathrm{mm})\end{array}$} & \multirow[b]{2}{*}{ Grouping } & \multicolumn{5}{|c|}{ Quality/kg } & \multirow{2}{*}{$\begin{array}{l}\text { Water- } \\
\text { cement } \\
\text { ratio }\end{array}$} & \multirow{2}{*}{$\begin{array}{l}\text { Sand } \\
\text { rate } \\
(\%)\end{array}$} & \multirow[b]{2}{*}{$\begin{array}{l}\text { Slump } \\
(\mathrm{mm})\end{array}$} \\
\hline & & Water & Cement & Sand & Crushed & Tailings & & & \\
\hline $\begin{array}{l}\text { Standard } \\
\text { specimen }\end{array}$ & A group & 2.05 & 5.12 & 5.22 & 12.16 & 0 & 0.4 & 30 & 34 \\
\hline \multirow{3}{*}{$0.15-0.3$} & $\mathrm{~B} 1(1 / 4)$ & 2.05 & 5.12 & 3.92 & 12.16 & 1.31 & 0.4 & 24.4 & 35 \\
\hline & $\mathrm{C} 1(1 / 2)$ & 2.05 & 5.12 & 2.62 & 12.16 & 2.62 & 0.4 & 17.7 & 30 \\
\hline & D1(3/4) & 2.05 & 5.12 & 1.31 & 12.16 & 3.92 & 0.4 & 9.7 & 25 \\
\hline \multirow{3}{*}{$0.3-0.6$} & $\mathrm{~B} 2(1 / 4)$ & 2.05 & 5.12 & 3.92 & 12.16 & 1.31 & 0.4 & 24.4 & 36 \\
\hline & $\mathrm{C} 2(1 / 2)$ & 2.05 & 5.12 & 2.62 & 12.16 & 2.62 & 0.4 & 17.7 & 30 \\
\hline & $\mathrm{D} 2(3 / 4)$ & 2.05 & 5.12 & 1.31 & 12.16 & 3.92 & 0.4 & 9.7 & 28 \\
\hline
\end{tabular}

\section{Test analysis}

\subsection{Slump test analysis}

Test several concrete above the slump and found only a small amount of slurry precipitation from the bottom. By analyzing the iron ore tailings $0.15-0.3 \mathrm{~mm}, 0.3-0.6 \mathrm{~mm}$ formulated seven kinds of concrete mixture ratio of sand rate and slump curve drawn in Figure. $2^{[6]}$.

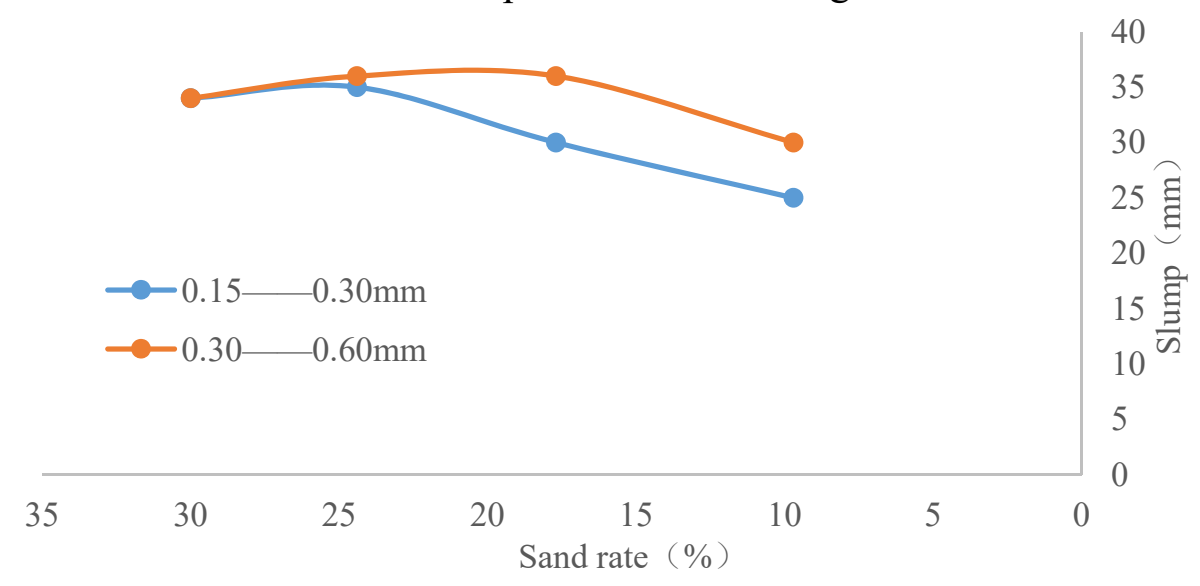

Figure. 2. Sand rate and slump curve

From Table 3 and Fig. 2, it can be seen that with the increase of sand rate, the amount of gravel is not enough to be surrounded by a small amount of grout, which does not provide sufficient lubrication. This situation will not only reduce the fluidity of concrete mix, but also affect its holding and water retention, resulting in the separation of imagination. For Figure. 2, we can see that when the sand rate is $24.4 \%$, the corresponding slump is about 36 , at this time, the sand rate and water-cement ratio are better than those of the designed concrete ${ }^{[7]}$.

\subsection{Workability Analysis}

In the production of specimens, the main factors affecting the workability of concrete should be the change of the amount of fine aggregate, the volume of coarse aggregate in fixed concrete is $0.0044 \mathrm{~m}^{3}$, and the amount of natural sand and iron tailings is calculated. The amount of the mix is shown in Table 3, the amount of fine aggregate changes on the workability of concrete shown in Figure. 4. 


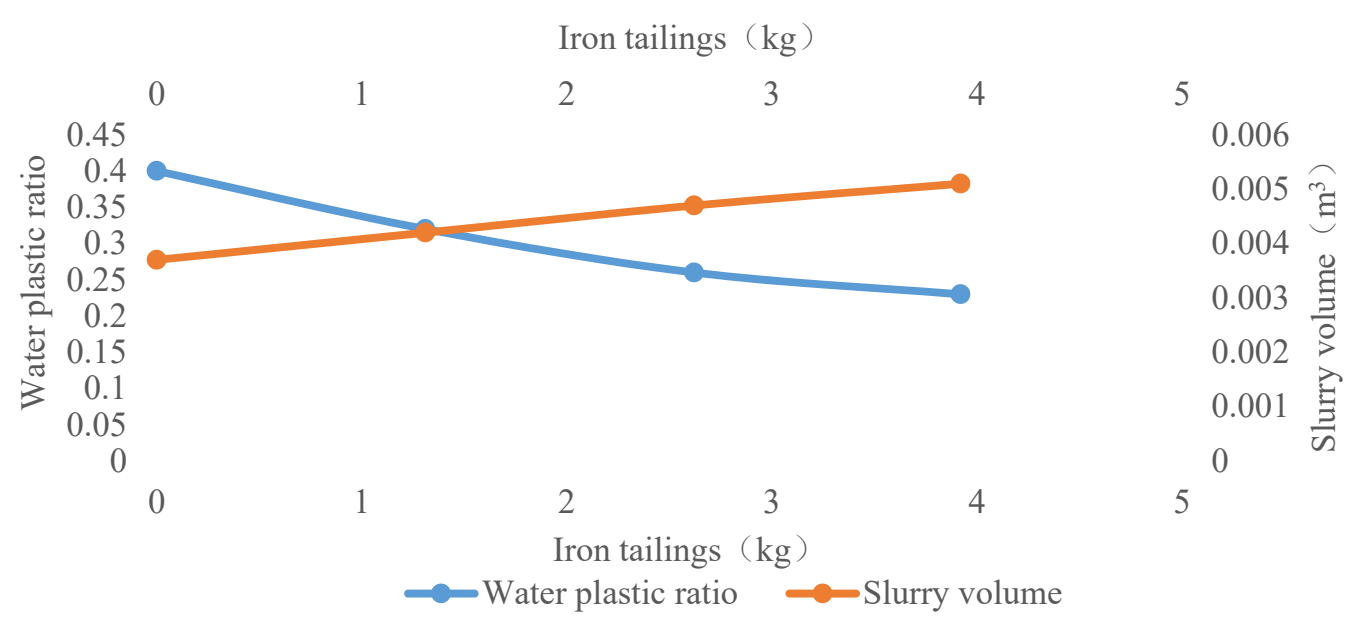

Fig. 3. Curve of changeability of cement concrete at the time of accumulation of coarse aggregate

It can be observed from Fig. 3 that the amount of cementitious material in cement concrete gradually increases with the increase of the amount of iron tailings in the mortar when the bulk volume of the coarse aggregate in the concrete mixture prepared is fixed at 0.0044 . The increase of cementitious material will increase the heat of hydration, which is not conducive to the durability of concrete. Therefore, the incorporation of iron tailings is not too good for concrete performance.

\subsection{Mechanical Analysis}

During the whole test, the cubical specimens $(150 \mathrm{~mm} \times 150 \mathrm{~mm} \times 150 \mathrm{~mm})$ were cured in freshwater environment at 4 cycles and the water temperature was between $15{ }^{\circ} \mathrm{C}$ and $25^{\circ} \mathrm{C}$ during compressive strength testing. When the compressive strength was tested Optional hydraulic press, which sand rate of compressive strength curve shown in Figure. 4.

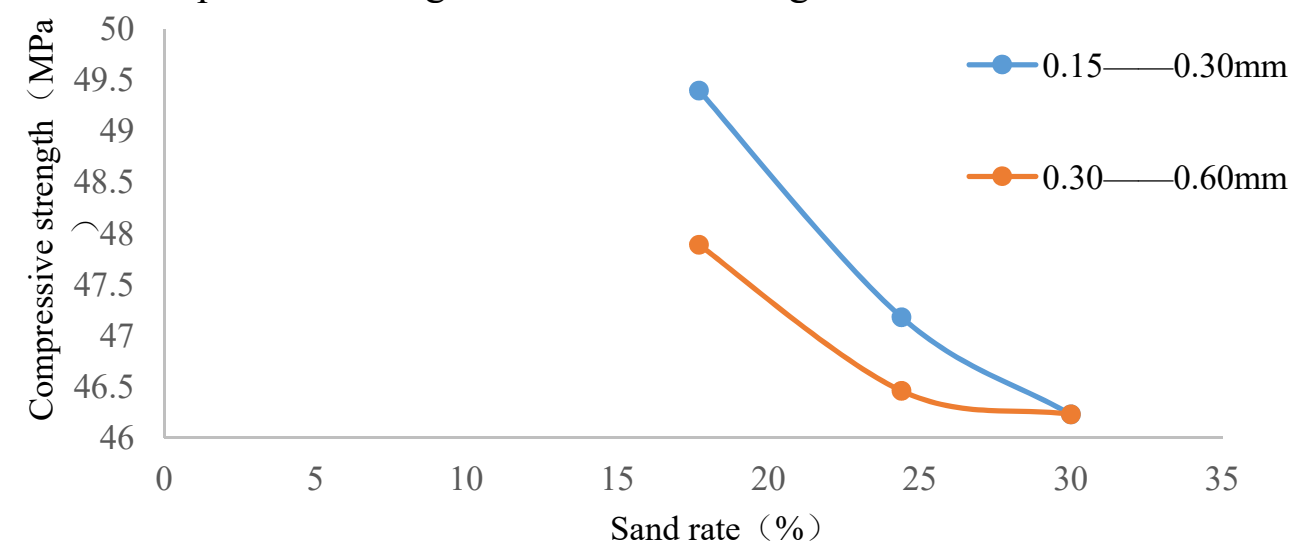

Figure. 4. Sand rate of compressive strength curve

The compressive strength of concrete increases with the time in the $28 \mathrm{~d}$ range. As shown in Fig. 4 , with the increase of sand rate, the strength of concrete produced by iron tailings instead of natural sand first increases and then decreases, and the sand rate is $13 \%--23 \%$ of the best concrete strength; iron tailings sand particle size $(0.15--0.30 \mathrm{~mm})$ when the concrete strength has a maximum of 49.4MPa.

\section{Summary}

(1) The use of iron ore tailings can not only solve the problem of iron tailings storage, natural sand supply and raw material cost, but also turn waste into treasure, improve the environment and make contributions to economic construction.

(2) When the sand rate is $24.4 \%$, the corresponding slump is about 36 , the water-cement ratio and sand rate at this time design the concrete flow better. 
(3) When the volume of coarse aggregate is $0.0044 \mathrm{~m}^{3}$, the mixture decreases with the increase of tailing volume, so the incorporation of iron tailings is not conducive to the workability of concrete, To some extent reduce its workability.

(4) Under normal curing conditions, the compressive strength of concrete prepared by substituting natural iron sand with iron tailings first increases and then decreases, and the sand strength is the best between $13 \%--23 \%$.

\section{Acknowledgement}

This research was financially supported by the National Natural Science Foundation of China (Project Number: 211021130246)

This work was supported by the Special Found for Basic Scientific Research of Central college of Changan University (300102218408). The authors gratefully acknowledged their financial support.

\section{References}

[1] Li Hong, Fu Zhi. Design requirements for mix proportion of pavement concrete [J] .Highroad, 2003, (07): 10-24.

[2] YAN Man-zhi, BAI Li-mei, ZHANG Yun-peng, ZHANG Jin-rui. Current Status, Problems and Countermeasures of Comprehensive Utilization of Tailings in China [J]. Mining Industry Letters, 2008, (07): 9-13.

[3] Hou Yunfen, Jia Xin. Effects of iron ore tailings on the workability of concrete [J]. Comprehensive Utilization of Fly Ash, 2013, (02): 27-30.

[4] Fang Zhengping, Wang Chengrong. Pavement cement concrete mix design optimization [J]. Taizhou Vocational and Technical College

[5] Journal of Wuhan University of Technology, 2009,31 (07): 104-107 Comment for this article: Feedback Author Email Title Code Content Copyright by Wuhan University of Technology.

[6] Xiang Rongjiang, Tang Ke, Xu Sensen, Fei Aiping. Effect of iron tailings replacing river sand on the strength of road concrete [J]. Science and Technology Innovation and Application, 2015, (34): $240-241$.

[7] Tang Ke, Xiang Rongjiang, Wang He, Fei Aiping, Zhang Tiezhi. Experimental study on mechanical properties of cement concrete with iron tailings particles[J]. Journal of Liaoning Provincial College of Communications, 2015,17(05): 17-22. 